\title{
A generally applicable synthesis of amino acid p- nitroanilides as synthons
}

\author{
Citation for published version (APA):
}

Rijkers, D. T. S., Hemker, H. C., Nefkens, G. H. L., \& Tesser, G. I. (1993). A generally applicable synthesis of amino acid p-nitroanilides as synthons. In C. H. Schneider, \& A. N. Eberle (Eds.), Peptides 1992: Proceedings of the Twenty-Second European Peptide Symposium September 13-19, 1992, Interlaken, Switzerland (1 ed., pp. 175-176). Springer. European Peptide Symposia Vol. 2

Document status and date:

Published: 01/01/1993

Document Version:

Publisher's PDF, also known as Version of record

\section{Please check the document version of this publication:}

- A submitted manuscript is the version of the article upon submission and before peer-review. There can be important differences between the submitted version and the official published version of record.

People interested in the research are advised to contact the author for the final version of the publication, or visit the DOI to the publisher's website.

- The final author version and the galley proof are versions of the publication after peer review.

- The final published version features the final layout of the paper including the volume, issue and page numbers.

Link to publication

\footnotetext{
General rights rights.

- You may freely distribute the URL identifying the publication in the public portal. please follow below link for the End User Agreement:

www.umlib.nl/taverne-license

Take down policy

If you believe that this document breaches copyright please contact us at:

repository@maastrichtuniversity.nl

providing details and we will investigate your claim.
}

Copyright and moral rights for the publications made accessible in the public portal are retained by the authors and/or other copyright owners and it is a condition of accessing publications that users recognise and abide by the legal requirements associated with these

- Users may download and print one copy of any publication from the public portal for the purpose of private study or research.

- You may not further distribute the material or use it for any profit-making activity or commercial gain

If the publication is distributed under the terms of Article $25 \mathrm{fa}$ of the Dutch Copyright Act, indicated by the "Taverne" license above, 


\title{
A generally applicable synthesis of amino acid $p$-nitroanilides as synthons
}

\author{
Dirk T.S. Rijkers ${ }^{\mathrm{a}, \mathrm{b}}$, H. Coenraad Hemker ${ }^{\mathrm{b}}$, Gerard H.L. Nefkens ${ }^{\mathrm{a}}$ and \\ Godefridus I. Tesser ${ }^{2}$ \\ ${ }^{a}$ Catholic University of Nijmegen, Department of Organic Chemistry, Toernooiveld, \\ 6525 ED Nijmegen, The Netherlands \\ ${ }^{b}$ University of Limburg, Faculty of Medicine, Department of Biochemistry, \\ P.O. Box 616, 6200 MD Maastricht, The Netherlands
}

\section{Introduction}

Amino acid $p$-nitroanilides are versatile chromogenic substrates for proteolytic enzymes [1]. Their synthesis is problematic because of the low nucleophilicity of p-nitroaniline, since the current coupling methods of peptide synthesis appear inadequate. In an earlier paper we mentioned the applicability of phosphorus oxychloride as condensing agent in the synthesis of protected arginine $p$-nitroanilides [2]. We now describe here the use of this reagent in the synthesis of orthogonally protected $p$-nitroanilides and their transformation into synthons for chromogenic substrates.

\section{Results and Discussion}

We found that phosphorus oxychloride [3] is an excellent condensing agent for amines and alcohols (J. Broos, personal communication) of low nucleophilicity (Scheme 1). Virtually all Boc- and Z-protected amino acid p-nitroanilides were obtained in high yield (70-90\%) in an optically pure form, some being given in Table 1 . We also found Boc-Ala-pNA to be excellently stable in $50 \%$ piperidine in DMF, which prompted us to synthesize Fmoc-amino acid $p$-nitroanilides, which have not been mentioned in the literature until now (Table 1).The use of Fmoc as $\alpha$-amino protection allows side chain protections which can be cleaved off under mildly acidic conditions at the end of the synthesis. As an example, Scheme 2 depicts the synthesis of the chromogenic substrate (S2238) used in the determination of thrombin.

Bz-1le-Glu-Gly-Arg-pNA.HCl (S2222), Bz-lle-Glu(N-piperidyl)-Gly-ArgpNA.HCl (S2337), from Boc-Arg-pNA.HCl and H-D-Val-Leu-Lys-pNA.2HCl

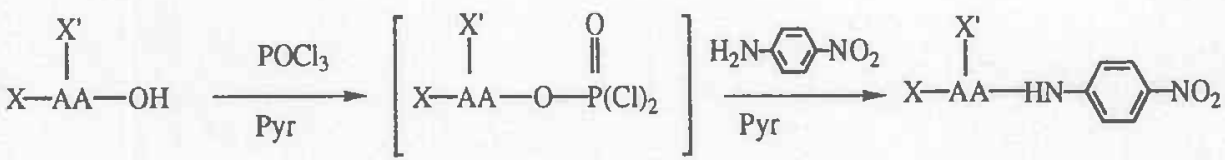

Scheme 1. Equimolar amounts of phosphorus oxychloride and carboxylic acid are required in this procedure. $X$ symbolizes an $\alpha$-amino protective group, $X^{\prime}$ a side-chain protection and $A A$ stands for an amino acid. 
Table 1 Some protected amino acid p-nitroanilides sythesized with phosphorus oxychloride as condensing
agent

\begin{tabular}{|c|c|c|c|c|c|c|c|}
\hline & $Y(\%)$ & m.p. $\left({ }^{\circ} \mathrm{C}\right)$ & $\alpha_{D}$ & & $Y(\%)$ & m.p. $\left({ }^{\circ} \mathrm{C}\right)$ & $\alpha_{D}$ \\
\hline Boc-Glu(OBzl)-pNA & 84 & foam & $-7.9^{*}$ & Fmoc-Glu(OtBu)-pNA & 83 & 98 & $-26.8^{b}$ \\
\hline Boc-Lys(Z)-pNA & 84 & foam & $-8.1^{\mathrm{z}}$ & Fmoc-Ser(tBu)-pNA & 79 & foam & $-36.2^{b}$ \\
\hline Boc-Arg(HCl)-pNA & 91 & 187 & $-12.8^{a}$ & Fmoc-Tyr-(tBu)-pNA & 79 & 94 (dec.) & $+24.5^{b}$ \\
\hline Z-Arg(HCl)-pNA & 96 & 174 & $-10.7^{2}$ & Fmoc-Arg(HCl)-pNA & 88 & 96 (dec.) & $-45.5^{b}$ \\
\hline $\mathrm{Msc}-\mathrm{Arg}(\mathrm{HCl})$-pNA & 65 & amorph & $-12.4^{a}$ & Fmoc-Lys(Boc)-pNA & 81 & $116-117$ & $-23.3^{b}$ \\
\hline Fmoc-Gly-pNA & 89 & $212-213$ & & Fmoc-Cys(Trt)-pNA & 90 & foam & $-18.8^{b}$ \\
\hline Fmoc-Phe-pNA & 88 & $197-199$ & $+13.3^{b}$ & Fmoc-His(Trt)-pNA & 95 & foam & $-6.1^{b}$ \\
\hline Fmoc-Val-pNA & 70 & 189-191 & $-27.2^{b}$ & Fmoc-Asn(Trt)-pNA & 71 & $214-215$ & $-25.3^{b}$ \\
\hline Fmoc-Met-pNA & 79 & 183 & $-39.1^{b}$ & & & & \\
\hline
\end{tabular}

c $=1, \mathrm{MeOH}$.

${ }^{b} \mathrm{c}=1, \mathrm{DMF}$.

(S2251), from Boc-Lys(Z)-pNA or Fmoc-Lys(Boc)-pNA, were synthesized in high yield as substrates for factor $\mathrm{X}_{\mathrm{a}}$ and plasmin, respectively, and exhibited the known kinetic data. Our conclusion, that phosphorus oxychloride is a powerful condensing agent in the synthesis of $p$-nitroanilides, is confirmed by these results.

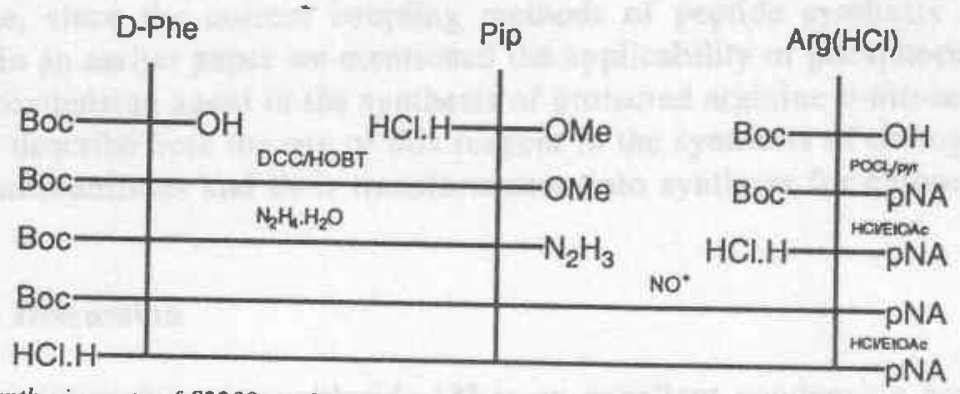

Scheme 2. Synthesis-route of $\$ 2238$, a chromogenic substrate for thrombin.

\section{References}

1. Hemker, H.C. (Ed.) Handbook of Synthetic Substrates for the Coagulation and Fibrinolytic System, Martinus Nijhoff Publishers, Boston, MA, 1983

2. Rijkers, D.T.S., Hemker, H.C., Nefkens, G.H.L. and Tesser, G.I., Rec. Trav. Chim. Pays-Bas, 10(1991) 347

3. Used for the first time as coupling reagent in peptide synthesis by Wieland et al., see: Liebigs Ann. Chem., 599(1956)70. The synthesis of an amino acid p-nitroanilide with phosphorus oxychloride was for the first time carried out by one of us (G.I.T.) and recommended by Planta, R.J. and Gruber, M., Biochim. Biophys. Acta. 